\title{
Current perspective on rituximab in rheumatic diseases
}

This article was published in the following Dove Press journal:

Drug Design, Development and Therapy

3 October 2017

Number of times this article has been viewed

\section{Tommaso Schioppo \\ Francesca Ingegnoli}

Department of Clinical Sciences and Community Health, Division of Rheumatology, ASST Pini, Università degli Studi di Milano, Milano, Italy
Correspondence: Francesca Ingegnoli Department of Clinical Sciences and Community Health, Division of Rheumatology, ASST Pini, Università degli Studi di Milano, Piazza Cardinal Ferrari I, 20122 Milano, Italy

Tel +3925829 6456

Fax +39 258296804

Email francesca.ingegnoli@unimi.it
Abstract: The steadily increasing knowledge regarding pathogenetic mechanisms in autoimmune rheumatic diseases has paved the way to different therapeutic approaches. In particular, the market entry of biologics has dramatically modified the natural history of rheumatic chronic inflammatory diseases with a meaningful impact on patients' quality of life. Among the wide spectrum of available biological treatments, rituximab (RTX), first used in the treatment of non-Hodgkin's lymphoma, was later approved for rheumatoid arthritis and anti-neutrophil cytoplasmic antibodies-associated vasculitis. Nowadays, in rheumatology, RTX is also used with off-label indications in patients with systemic sclerosis, Sjögren's syndrome and systemic lupus erythematosus. RTX is a monoclonal antibody directed to CD20 molecules expressed on the surfaces of pre-B and mature B lymphocytes. It acts by causing apoptosis of these cells with antibody- and complement-dependent cytotoxicity. As inflammatory responses to cell-associated immune complexes are key elements in the pathogenesis of several autoimmune rheumatic diseases, such an approach might be effective in these patients. In fact, RTX, by promoting the rapid and long-term depletion of circulating and lymphoid tissue-associated B cells, leads to a lower recruitment of these effector cells at sites of immune complex deposition, thus reducing inflammation and tissue damage. RTX is of the most interest to rheumatologists as it represents an important additional therapeutic approach. Thus, the advent in clinical practice of approved RTX biosimilars, such as CT-P10, may be of help in improving treatment access as well as in reducing costs.

Keywords: rituximab, rheumatoid arthritis, ANCA-associated vasculitis, systemic sclerosis, Sjögren's syndrome, systemic lupus erythematosus, biologics, biosimilars, myositis, pregnancy, vaccination

\section{Introduction}

Rituximab (RTX) is a chimeric mouse/human monoclonal antibody that targets the transmembrane protein CD20 molecule on the surfaces of some but not all B cells. RTX by binding to CD20, that is expressed on pre-B and mature B lymphocytes, leads to apoptosis of these cells with antibody- and complement-dependent cytotoxicity (Figure 1). This mechanism of action leads, in most patients, to a selective peripheral B cell depletion for more than 24 weeks. However, other niches of B cells (eg, those in the synovium) are variably depleted. RTX has no or little effects on autoantibody levels, which are mainly secreted by mature plasma cells, but it is active on memory and mature B cells. Repopulation of peripheral B cells occurs after 6-9 months from RTX course, and it can be of particular utility in patients with scarce adherence to daily therapy.

Nowadays, RTX is a well-established biologic agent for the treatment of some rheumatic autoimmune diseases such as refractory rheumatoid arthritis (RA) ${ }^{1,2}$ and anti-neutrophil cytoplasmic antibodies (ANCAs)-associated vasculitis (AAV). ${ }^{3}$ 


\section{Fc $\gamma$-R/CR-mediated Complement- phagocytosis or ADCC mediated cytotoxicity}

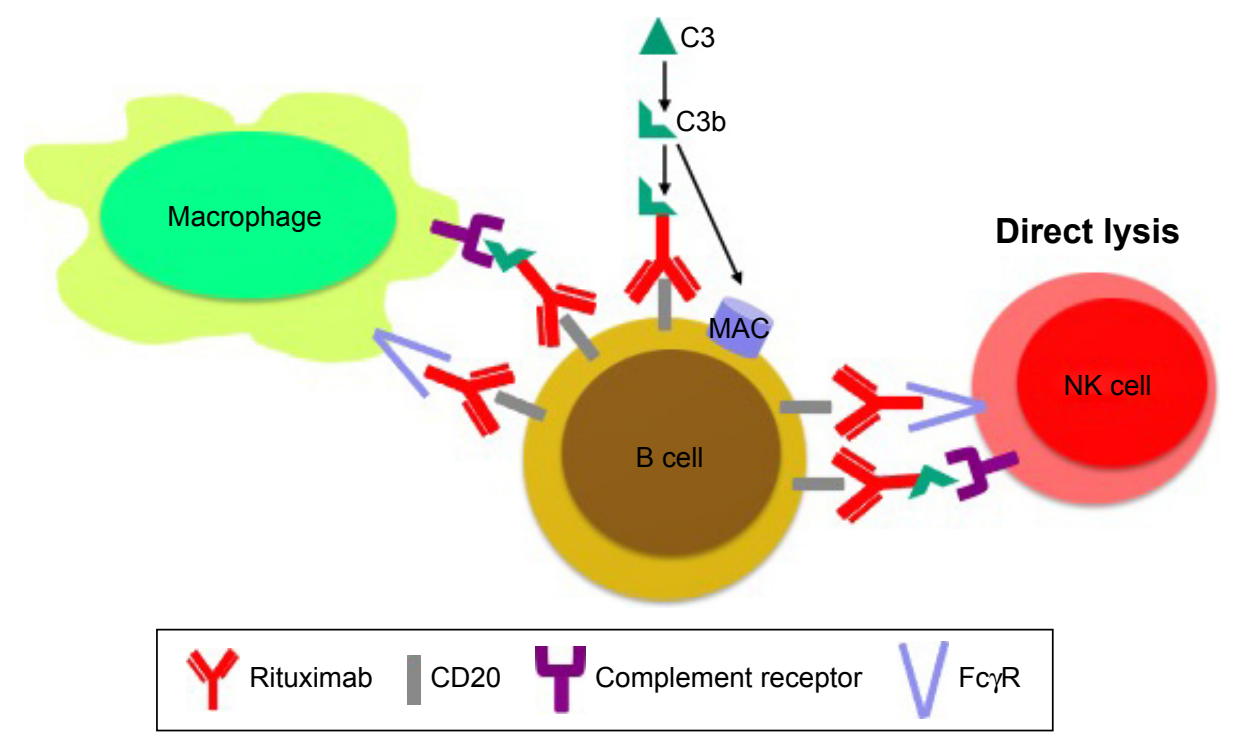

Figure I RTX has different mechanisms of action through activation of the complement cascade which leads to a direct lyse B cells by complement-mediated cytotoxicity, the recognition by both Fc $\gamma$ receptors and complement receptors I and 3 on macrophages causes phagocytosis and antibody-dependent cell-mediated cytotoxicity and interaction with NK cells via Fc $\gamma \mathrm{RIII}$ and complement receptor 3.

Abbreviations: ADCC, antibody-dependent cell-mediated cytotoxicity; NK, natural killer; RTX, rituximab.

At the moment, RTX regimen is intravenous (IV) with slightly different dosages in rheumatic diseases ranging from $1,000 \mathrm{mg}$ administered 2 weeks apart in RA to $375 \mathrm{mg} / \mathrm{m}^{2}$ weekly for 4 weeks in AVV. In all patients, premedication before each infusion with methylprednisolone $100 \mathrm{mg} \mathrm{IV}$, acetaminophen and antihistamines is highly recommended.

This review provides insight into the current on- and off-label use of RTX in rheumatic diseases with a focus on the advent of biosimilars.

\section{RTX in RA}

In 2004, the first randomized double-blind placebocontrolled trial in patients with long-standing active RA, despite methotrexate treatment, demonstrated that a single course of two infusions of RTX, alone or in combination with either cyclophosphamide or continued methotrexate, provided significant improvement in clinical response at weeks 24 and $48 .{ }^{4}$

The efficacy and safety of different RTX doses plus methotrexate, with or without glucocorticoids, in patients with active RA who did not respond to disease-modifying antirheumatic drugs (DMARDs) were tested in the DANCER study. ${ }^{5}$ Both RTX doses (ie, $500 \mathrm{mg}$ or $1,000 \mathrm{mg}$ on days 1 and 15) were effective and well tolerated. ${ }^{5}$

Moreover, the MIRROR study showed that RTX dose escalation from two doses of $500 \mathrm{mg}$ to two doses of
1,000 mg did not improve clinical response. Retreatment strategy from week 24 supported a sustained suppression of disease activity through to week $48 .^{6}$

The Phase III SERENE study showed the efficacy and safety of RTX plus methotrexate in patients with active RA who were naive to prior biological treatment. RTX both $2 \times 500 \mathrm{mg}$ and $2 \times 1,000 \mathrm{mg}$ plus methotrexate significantly improved clinical outcomes at weeks 24 and $48 .^{7}$

Further studies in patients with RA with inadequate response to antitumor necrosis factor (anti-TNF) therapies showed that a single course of RTX associated with methotrexate therapy provided significant improvements in disease activity and progression of radiological damage. ${ }^{8-10}$ A sustained clinical efficacy was better maintained after two courses of RTX about 6 months apart. ${ }^{10}$

In 2011, a Phase IIIb open-label prospective study (RESET) confirmed that RTX is an effective treatment option for patients who have not responded to a single TNF- $\alpha$ inhibitor, particularly for seropositive patients. ${ }^{11-13}$

The MIRAR study and real-life data indicate that switching to RTX is a successful treatment option for patients with RA failing on TNF antagonists. ${ }^{12,14,15}$

Treatment with RTX $(2 \times 1,000 \mathrm{mg})$ in combination with MTX has been shown to be an effective treatment for patients with MTX-naive RA, leading to sustained improvements in radiographic, clinical and functional outcomes over 2 years. ${ }^{16-18}$ 


\section{RTX in AAV}

AAV are rare diseases classified on the basis of both vascular inflammation distribution and the presence or absence of granulomatosis and asthma. AAV includes microscopic polyangiitis (MPA), granulomatosis with polyangiitis (GPA; also known as Wegener's granulomatosis) and eosinophilic GPA (also known as Churg-Strauss syndrome). ${ }^{19}$

RTX was approved by the Food and Drug Administration (FDA) for the treatment of patients with GPA and MPA in $2011 .^{3}$

Two retrospective open-label studies reported remission (Birmingham Vasculitis Activity Score Modified for Wegener's Granulomatosis: 0) in all the 21 AAV patients enrolled. ${ }^{20,21}$ Based on these successful results, the first seminal multicenter randomized double-blind controlled trial on RTX in AAV (RAVE) trial was designed. ${ }^{22}$ This study demonstrated that RTX therapy was not inferior to daily cyclophosphamide for induction of remission in severe AAV as a higher percentage of remission occurred in RTX-treated patients (64\% vs 53\%). ${ }^{22}$ Moreover, RTX appeared to be superior in patients with relapsing RA.

Results from 18-month extension of the RAVE trial demonstrated that a single course of RTX was as effective as continuous conventional immunosuppressive therapy for the induction and maintenance of remission in AAV. ${ }^{23}$
Further analysis of the RAVE trial showed that an increase in PR3-ANCA levels during remission was related to an increased risk of relapse, particularly among patients with renal involvement or alveolar hemorrhage. ${ }^{24}$

RTX was also studied for remission maintenance. The randomized controlled studies MAINRITSAN and RITAZEREM demonstrated that RTX was superior to azathioprine for remission maintenance in AAV, without increasing the adverse event rate. ${ }^{25,26}$

\section{RTX in systemic lupus erythematosus (SLE)}

Since B cells play a critical role in SLE, in the past 10 years, targeted B cell therapies have been proposed in these patients. ${ }^{27}$

B cell depletion therapy based on RTX is still unlicensed for SLE, but it is used to treat early onset and refractory disease. The most important studies on RTX in SLE are reported in Table 1. RTX has not been designed for SLE patients, but many uncontrolled studies described its utility in SLE patients who are refractory to conventional treatments. ${ }^{2-33}$ In fact, RTX is a recommended option in SLE nephritis in both European League Against Rheumatism (EULAR) and American College of Rheumatology guidelines. ${ }^{34}$

RTX failed primary end points in two randomized clinical trials (RCTs; EXPLORER in non-renal SLE and LUNAR

Table I Results from the off-label use of RTX in SLE

\begin{tabular}{|c|c|c|c|c|}
\hline Studies & Study design & Number of patients & Drug regimen & Results \\
\hline Merrill et $\mathrm{al}^{35}$ & $\begin{array}{l}\text { Prospective } \\
\text { Randomized (2:I) } \\
\text { Double-blind } \\
\text { Placebo-controlled }\end{array}$ & 257 SLE & $\begin{array}{l}\text { RTX I g or placebo on } \\
\text { days I, I5, } 168 \text { and } 182\end{array}$ & $\begin{array}{l}\text { Extra-renal manifestations: no difference } \\
\text { between RTX and placebo }\end{array}$ \\
\hline Rovin et $\mathrm{al}^{36}$ & $\begin{array}{l}\text { Prospective } \\
\text { Randomized (I:I) } \\
\text { Double-blind } \\
\text { Placebo-controlled }\end{array}$ & I44 SLE & $\begin{array}{l}\text { RTX I g or placebo on } \\
\text { days I, I5, } 168 \text { and } 182\end{array}$ & $\begin{array}{l}\text { Primary end point: no renal response at } \\
\text { week } 52 \\
\text { Reduction in anti-dsDNA and C3/C4 levels }\end{array}$ \\
\hline Leandro et $\mathrm{al}^{28}$ & $\begin{array}{l}\text { Prospective } \\
\text { Open-label study }\end{array}$ & 24 SLE & $\begin{array}{l}\text { In most cases: RTX I g, } \\
\text { CYC } 750 \text { mg and MPD } \\
250 \text { mg } 2 \text { weeks apart }\end{array}$ & $\begin{array}{l}\text { At } 6 \text { months: } \\
\text { BILAG, anti-dsDNA and } C 3 \text { improved }\end{array}$ \\
\hline Lu et $\mathrm{al}^{29}$ & Retrospective & $\begin{array}{l}50 \text { SLE ( } 45 \text { with available } \\
\text { follow-up at } 6 \text { months) }\end{array}$ & $\begin{array}{l}46 \text { of } 50: \text { RTX I g, CYC } \\
750 \mathrm{mg} \text { and MPD I00- } \\
250 \mathrm{mg} 2 \text { weeks apart }\end{array}$ & $\begin{array}{l}\text { BILAG } \\
\text { Remission: } 42 \% \\
\text { Partial remission: } 47 \% \\
\text { Anti-dsDNA antibody titers: decreased } \\
\text { C3: increased }\end{array}$ \\
\hline $\begin{array}{l}\text { Diaz-Lagares } \\
\text { et } \mathrm{al}^{30}\end{array}$ & $\begin{array}{l}\text { Retrospective } \\
\text { Multicenter } \\
\text { Registry }\end{array}$ & $\begin{array}{l}\text { I } 64 \text { biopsy-proven lupus } \\
\text { nephropathy }\end{array}$ & $\begin{array}{l}\text { RTX with corticosteroids } \\
(99 \%) \text { and } \\
\text { immunosuppressive agents } \\
\text { (76\%, CYC and MMF) }\end{array}$ & $\begin{array}{l}\text { At } 6 \text { and } 12 \text { months: } \\
\text { Complete response: } 27 \% \text { and } 30 \% \\
\text { Partial response: } 40 \% \text { and } 37 \% \\
\text { No response: } 33 \% \\
\text { At } 12 \text { months, significant improvement in } \\
\text { proteinuria, albumin and protein/creatinine ratio } \\
\text { Better response in type III lupus nephropathy } \\
\text { Worse response in nephrotic syndrome and } \\
\text { renal failure at the time of RTX administration }\end{array}$ \\
\hline
\end{tabular}

(Continued) 
Table I (Continued)

\begin{tabular}{|c|c|c|c|c|}
\hline Studies & Study design & Number of patients & Drug regimen & Results \\
\hline Condon et $\mathrm{al}^{32}$ & $\begin{array}{l}\text { Cohort study } \\
\text { Prospective } \\
\text { Observational } \\
\text { Monocentric }\end{array}$ & $\begin{array}{l}50 \text { biopsy-proven lupus } \\
\text { nephropathy }\end{array}$ & $\begin{array}{l}\text { RTX I g and MPD } 500 \mathrm{mg} \\
2 \text { weeks apart, with MMF } \\
\text { as maintenance therapy }\end{array}$ & $\begin{array}{l}\text { At } 52 \text { weeks: } \\
\text { Responders: } 90 \% \\
\text { Complete biochemical remission: } 52 \% \\
\text { Partial biochemical remission: } 34 \% \\
\text { Relapses after } 65 . \text { I weeks (20-112) from } \\
\text { remission: } 12 \\
\text { Systemic flares: } 6\end{array}$ \\
\hline Witt et $\mathrm{al}^{33}$ & $\begin{array}{l}\text { Registry } \\
\text { Retrospective } \\
\text { Multicenter } \\
\text { Noninterventional }\end{array}$ & 85 active SLE & $\begin{array}{l}\text { RTX I g } 2 \text { weeks apart } \\
\text { 67: I course } \\
\text { 6: } 2 \text { courses } \\
\text { 2: } 3 \text { courses }\end{array}$ & $\begin{array}{l}\text { Complete response: } 46.8 \% \\
\text { Partial response: } 34.2 \% \\
\text { No response: } 19.0 \% \\
\text { SLEDAl: } 12.2 \rightarrow 3.3 \\
\text { Clinical (tender and swollen joint counts, } \\
\text { fatigue, myalgia, general well-being, Raynaud's } \\
\text { phenomenon) and laboratory (anti-dsDNA, } \\
\text { complement factors, hematologic parameters, } \\
\text { proteinuria): improvement }\end{array}$ \\
\hline Albert et $\mathrm{al}^{37}$ & $\begin{array}{l}\text { Prospective } \\
\text { Open-label } \\
\text { Multicenter }\end{array}$ & $\begin{array}{l}24 \text { mild and moderate } \\
\text { SLE without concomitant } \\
\text { immunosuppressive therapy }\end{array}$ & RTX I g 2 weeks apart & $\begin{array}{l}\text { I-year follow-up } \\
\text { In } 18 \text { patients, B cell levels in peripheral blood } \\
\text { were available: } \\
\text { Effective CDI9+ B cell depletion: } 17 \\
\text { B cell return before } 24 \text { weeks: } 6 \\
\text { SLEDAI: improvement by week } 55 \text { in } 70 \% \\
\text { Approximately one-third of the patients } \\
\text { developed human anti-chimeric antibody titers } \\
\text { correlated with poor B cell depletion }\end{array}$ \\
\hline $\begin{array}{l}\text { Lindholm } \\
\text { et } \mathrm{al}^{38}\end{array}$ & $\begin{array}{l}\text { Retrospective } \\
\text { Monocentric }\end{array}$ & $\begin{array}{l}26 \text { SLE with active nephritis } \\
\text { (I7) or autoantibody-mediated } \\
\text { cytopenias (thrombocytopenia: } \\
10 \text { and hemolytic anemia: } 4 \text { ) } \\
\text { refractory to conventional } \\
\text { immunosuppressive treatment }\end{array}$ & $\begin{array}{l}\mathrm{RTX} 375 \mathrm{mg} / \mathrm{m}^{2} / \text { week } \\
\text { for } 4 \text { weeks added } \\
\text { to conventional } \\
\text { immunosuppressive } \\
\text { therapy }\end{array}$ & $\begin{array}{l}\text { Complete B cell depletion in all patients } \\
\text { Complete or partial response in II patients } \\
\text { with lupus nephritis was achieved after } \\
6-12 \text { months } \\
\text { Significant increase in platelet count after I month } \\
\text { Complete platelet count normalization at } \\
6 \text { weeks in five patients }\end{array}$ \\
\hline $\begin{array}{l}\text { Ramos-Casals } \\
\text { et } \mathrm{al}^{39}\end{array}$ & $\begin{array}{l}\text { Multicenter } \\
\text { Registry }\end{array}$ & $\begin{array}{l}\text { I96 with systemic autoimmune } \\
\text { diseases refractory to standard } \\
\text { therapies } \\
\text { I07 SLE }\end{array}$ & $\begin{array}{l}\text { 91: RTX } 375 \mathrm{mg} / \mathrm{m}^{2} / \text { week } \\
\text { for } 4 \text { weeks } \\
\text { 16: RTX I g } 2 \text { weeks apart }\end{array}$ & $\begin{array}{l}\text { Mean follow-up of } 26.05 \pm 1.62 \text { months } \\
\text { Complete response: } 47 \% \\
\text { Partial response: } 34 \% \\
\text { No response: } 24 \% \\
\text { Relapses in responders: } 25 \% \\
\text { Deaths: } 5 \%\end{array}$ \\
\hline Vital et $\mathrm{a}^{40}$ & $\begin{array}{l}\text { Open-label } \\
\text { Monocentric } \\
\text { Observational }\end{array}$ & 39 active SLE & RTX I g 2 weeks apart & $\begin{array}{l}\text { BILAG: significantly reduced } \\
\text { Major clinical response: } 51 \% \\
\text { Partial clinical response: } 31 \% \\
\text { Relapse after } 6-18 \text { months: } 50 \% \\
\text { B cell numbers: no response in } 21 \text { patients after } \\
\text { RTX (included seven patients with no response) } \\
\text { Memory B cell and plasmablast repopulation } \\
\text { after } 26 \text { weeks faster in patients with } \\
\text { earlier relapse }\end{array}$ \\
\hline $\begin{array}{l}\text { Fernandez- } \\
\text { Nebro et } \mathrm{al}^{41}\end{array}$ & $\begin{array}{l}\text { Multicenter } \\
\text { Retrospective } \\
\text { Longitudinal study }\end{array}$ & $\begin{array}{l}\text { I I } 6 \text { SLE nonresponder to } \\
\text { standard therapy }\end{array}$ & $\begin{array}{l}65 \%: \text { RTX I g } 2 \text { weeks } \\
\text { apart } \\
30 \%: \text { RTX } \\
375 \mathrm{mg} / \mathrm{m}^{2} / \text { week for } \\
4 \text { weeks } \\
5 \% \text { : others }\end{array}$ & $\begin{array}{l}\text { After } 6 \text { months: } \\
\text { Complete response: } 17 \% \\
\text { Partial response: } 44 \% \\
\text { After a mean follow-up of } 20.0 \pm 15.2 \text { months: } \\
\text { Responses: } 77.6 \% \\
\text { Relapses: } 38 \%\end{array}$ \\
\hline Terrier et al ${ }^{42}$ & $\begin{array}{l}\text { Registry } \\
\text { Observational } \\
\text { Prospective }\end{array}$ & I 36 SLE & $\begin{array}{l}\text { 60\%: RTX I g } 2 \text { weeks } \\
\text { apart } \\
\text { 36\%: RTX } 375 \mathrm{mg} / \mathrm{m}^{2} / \text { week } \\
\text { for } 4 \text { weeks } \\
4 \% \text { : others }\end{array}$ & $\begin{array}{l}\text { Safety of Estrogens in Lupus Erythematosus: } \\
\text { National Assessment (SELENA)-SLEDAI: } \\
\text { improvement in } 71 \% \\
\text { Relapses in } 41 \% \text { of responders with a good } \\
\text { response in } 91 \% \text { to retreatment }\end{array}$ \\
\hline
\end{tabular}


Table I (Continued)

\begin{tabular}{|c|c|c|c|c|}
\hline Studies & Study design & Number of patients & Drug regimen & Results \\
\hline \multirow[t]{10}{*}{ Pinto et al ${ }^{45}$} & Prospective & 42 severe and refractory SLE & RTX I g 2 weeks apart & Reduction in steroid requirement at 24 months \\
\hline & Observational & & & At 12-month follow-up, remission according to \\
\hline & Multicenter & & & proteinuria: \\
\hline & & & & Complete: $28 \%$ \\
\hline & & & & Partial: $36 \%$ \\
\hline & & & & At I2-month follow-up, remission according to \\
\hline & & & & creatinine clearance: \\
\hline & & & & Complete: $12.5 \%$ \\
\hline & & & & Partial: $33 \%$ \\
\hline & & & & No RTX reinfusion required: $80 \%$ \\
\hline
\end{tabular}

Abbreviations: BILAG, British Isles Lupus Assessment Group; CYC, cyclophosphamide; MMF, mycophenolate mofetil; MPD, methylprednisolone; RTX, rituximab; SLE, systemic lupus erythematosus; SLEDAI, Systemic Lupus Erythematosus Disease Activity Index.

in renal SLE). ${ }^{35,36}$ In recent years, interest in B cell therapies has been maintained as demonstrated by the approval of belimumab.

RTX is currently used for more severe forms and to achieve disease control rather than corticosteroid-sparing strategy in patients with lupus nephritis. Moreover, probably due to its efficacy in idiopathic autoimmune hemolytic anemia and idiopathic thrombocytopenia purpura (ITP), RTX is also used in patients with SLE complicated by thrombocytopenia and hemolytic anemia. RTX is less used in cutaneous and musculoskeletal SLE involvement. The efficacy of RTX in mucocutaneous manifestations is unclear, while RTX seems to be effective in articular manifestations. ${ }^{37-42}$

RTX has been also described as an effective therapy in antiphospholipid syndrome secondary to SLE in the prevention of recurrent thrombotic events..$^{43}$ Scarce and non-conclusive data are available on neuropsychiatric SLE. ${ }^{39-41,44,45}$

A study demonstrated that a single infusion of RTX was as effective as multiple doses with a reduction in cost therapy. ${ }^{46}$ Reports suggest RTX as an induction therapy followed by belimumab as maintenance. ${ }^{47}$ Two prospective clinical trials (NCT02260934 and NCT02284984 on ClinicalTrials.org) are currently ongoing to assess the efficacy of the sequential therapy with RTX followed by belimumab in SLE patients.

RTX is used differently all across Europe also for economical reasons. ${ }^{48}$

\section{RTX in Sjögren syndrome (SS)}

Traditional immunosuppressive therapies did not show effectiveness in RCTs. Nowadays, SS therapy is essentially based on symptomatic and supportive measures. As B cells play a pivotal role in SS pathogenesis, RTX has been suggested to be potentially useful. ${ }^{49}$ The most important studies on RTX in SS are listed in Table 2.
A meta-analysis published in 2016 evaluated 276 subjects (145 RTX and 131 placebo) from four RCTs: no statistically significant change regarding lacrimal gland function, as assessed by Schirmer test, was noted while an improvement in salivary gland production and fatigue were described at 24 weeks. ${ }^{50-53}$

Carubbi et $a^{54}$ reported on 41 patients with SS an improvement at 120 weeks in unstimulated saliva flow rate and a decrease in labial salivary gland lymphocytic infiltration as assessed by focus score in patients treated with RTX compared to patients treated with conventional therapies.

RTX has been demonstrated to be effective at 6 months as assessed by both the SS responder index and ultrasonography. ${ }^{55,56}$

According to recently published SS treatment recommendations, RTX should be used in selected patients who have not responded to conventional therapies for sicca syndrome and for some extra-glandular manifestations (vasculitis, arthritis, lung involvement, peripheral neuropathy and parotid involvement). ${ }^{57}$

Treatment with belimumab could decrease B cellactivating factor (BAFF) levels, B cell hyperactivation and salivary gland B cell infiltration. Sequential treatment with belimumab and RTX has been suggested. ${ }^{58,59}$ Synergic action of RTX and belimumab is now under investigation also in other rheumatic conditions (NCT02260934, NCT02631538 and NCT02284984 on ClinicalTrials.org).

A retrospective study by a Taiwanese group on 10 patients with SS complicated by interstitial lung disease treated with RTX reported pulmonary involvement stabilization. ${ }^{60}$

RTX retreatment seems to be reasonable in patients who responded to first course with RTX, as reported by two different groups. ${ }^{61,62}$

It would be extremely important to identify predictor factors for RTX response. Moreover, the most adequate RTX regimen should be assessed throughout a specific trial. 
Table 2 Results from the off-label use of RTX in SS

\begin{tabular}{|c|c|c|c|c|}
\hline Studies & Study design & Number of patients & Drug regimen & Results \\
\hline Dass et $\mathrm{al}^{50}$ & $\begin{array}{l}\text { Randomized } \\
\text { Double-blind } \\
\text { Placebo-controlled }\end{array}$ & $\begin{array}{l}\text { I } 7 \text { pSS and fatigue } \\
\text { VAS }>50\end{array}$ & $\begin{array}{l}\text { RTX I g } 2 \text { weeks } \\
\text { apart or placebo }\end{array}$ & $\begin{array}{l}\text { At 6-month follow-up: } \\
\text { Fatigue VAS: reduction }>20 \% \text { in RTX } \\
\text { HRQOL: SF- } 36 \text { better in RTX }\end{array}$ \\
\hline Meijer et $\mathrm{al}^{51}$ & $\begin{array}{l}\text { Randomized }(2: 1) \\
\text { Double-blind } \\
\text { Placebo-controlled }\end{array}$ & $\begin{array}{l}30 \text { active } \mathrm{pSS} \text { and a } \\
\text { rate of } \mathrm{SWS} \text { secretion } \\
\geq 0.15 \mathrm{~mL} / \text { minute }\end{array}$ & $\begin{array}{l}\text { RTX I g } 2 \text { weeks } \\
\text { apart or placebo }\end{array}$ & $\begin{array}{l}\text { Follow-up at 5, I2, 24, } 36 \text { and } 48 \text { weeks } \\
\text { Primary end point: } \\
\text { SWS: better in RTX } \\
\text { Secondary end points: } \\
\text { Laboratory (B cell and RF): better in RTX } \\
\text { Subjective variables (MFI and VAS): better in RTX } \\
\text { Extra-glandular manifestations: better in RTX } \\
\text { Better when compared to baseline values: SWS, B cell, RF, UWS, } \\
\text { lacrimal gland function, MFI, SF- } 36 \text { and sicca VAS }\end{array}$ \\
\hline $\begin{array}{l}\text { Devauchelle- } \\
\text { Pensec et } \text { al }^{52}\end{array}$ & $\begin{array}{l}\text { Randomized (I:I) } \\
\text { Placebo-controlled } \\
\text { Multicenter }\end{array}$ & $\begin{array}{l}\text { I } 20 \text { recent-onset or } \\
\text { systemic pSS with } \\
50 \mathrm{~mm} \text { or greater on } \\
\text { at least } 2 \text { of } 4 \text { VAS } \\
\text { (global disease, pain, } \\
\text { fatigue, dryness) }\end{array}$ & $\begin{array}{l}\text { RTX I g } 2 \text { weeks } \\
\text { apart or placebo }\end{array}$ & $\begin{array}{l}\text { At } 24 \text { weeks } \\
\text { Primary end points: } \\
\quad \text { Improvement of at least } 30 \mathrm{~mm} \text { in } 2 \text { of } 4 \text { VAS by week } 24 \text { : } \\
\text { no difference } \\
\text { Some subjective efficacy with RTX before } 24 \text { weeks }\end{array}$ \\
\hline Carubbi et $\mathrm{al}^{54}$ & $\begin{array}{l}\text { Prospective } \\
\text { Multicenter }\end{array}$ & $\begin{array}{l}41 \text { pSS with early } \\
\text { and active disease } \\
(E S S D A I \geq 6)\end{array}$ & RTX or DMARDs & $\begin{array}{l}\text { Follow-up for I } 20 \text { weeks (at weeks I2, 24, 48, 72, } 96 \text { and 120): } \\
\text { ESSDAI: better in RTX } \\
\text { Other clinical parameters (self-reported global disease } \\
\text { activity pain, sicca symptoms and fatigue VAS, UWS and } \\
\text { Schirmer's I test): better with RTX } \\
\text { Minor salivary gland biopsies at baseline and at week I20: } \\
\text { glandular infiltrate receded with RTX }\end{array}$ \\
\hline $\begin{array}{l}\text { Jousse-Joulin } \\
\text { et } \mathrm{al}^{56}\end{array}$ & $\begin{array}{l}\text { Randomized }(\mathrm{I}: \mathrm{I}) \\
\text { Double-blind } \\
\text { Placebo-controlled } \\
\text { Multicenter }\end{array}$ & $\begin{array}{l}28 \text { recent-onset or } \\
\text { systemic pSS with } \\
50 \text { mm or greater on } \\
\text { at least } 2 \text { of } 4 \text { VAS }\end{array}$ & $\begin{array}{l}\text { RTX I g } 2 \text { weeks } \\
\text { apart or placebo }\end{array}$ & $\begin{array}{l}\text { At 6-week follow-up: } \\
\text { Salivary gland echostructure: better in RTX (50\% vs } 7 \%) \\
\text { Gland sizes: no change } \\
\text { Vascularization: no change }\end{array}$ \\
\hline
\end{tabular}

$\begin{array}{lll}\text { Gottenberg } & \text { Registry } & 78 \text { pSS with systemic } \\ \text { et } \mathrm{al}^{61} & \text { Prospective } & \text { or severe glandular } \\ & & \text { involvement }\end{array}$

86\%: RTX I g

2 weeks apart I4\%: RTX $375 \mathrm{mg} / \mathrm{m}^{2} /$ week for 4 weeks Meiners et $\mathrm{al}^{62}$ Retrospective $\quad 15 \mathrm{pSS}$
RTX I g 2 weeks apart for two courses Median interval between courses: 103 weeks

Group I (14): low-dose RTX (two $375 \mathrm{~m}^{2}$ ) Group II: full-dose RTX (two I,000 g) (I7) Baseline serum BAFF: correlated with the proportion of SG

vs placebo (14) B cells and clinical response (higher levels in nonresponders) $\begin{array}{ll}\text { Delli et } \mathrm{al}^{64} & \text { Randomized (2:I) } \\ & \text { Double-blind }\end{array}$ Placebo-controlled
20 RTX-treated and RTX I g 2 weeks 10 placebo-treated pSS apart or placebo
Follow-up at 24 and 48 weeks after RTX treatment
Follow-up every 6 months for 5 years (78 patients with at least one follow-up)

ESSDAI: decreased

Median dosage of corticosteroid: decreased

41 retreatments

Better after both courses with RTX: ESSDAI, B cells, RF, MFI, IgG Improved significantly after first course but with a trend after second one: patient GDA and oral dryness VAS

Improved significantly only after first course: ocular dryness VAS SWS: stable during the first 24 weeks of both courses, but with a significant at week 48 of the first course

Less pronounced deterioration after the treatment course

At 24 weeks:

SSRI-30: $50 \%$ in both RTX groups

$B C D$ duration: similar in both groups

BCD duration: not associated with clinical response

Responders: lower baseline proportions of SG B cells

Biopsies at baseline and 12 weeks after treatment:

$B$ cells, number and the severity of lymphoepithelial lesions and germinal centers: reduced in RTX

T cells $(\mathrm{CD} 3+)$ : no change

CD20+ higher in responders

Abbreviations: BAFF, B cell-activating factor; BCD, B cell depletion; DMARDs, disease-modifying antirheumatic drugs; ESSDAI, EULAR Sjögren's syndrome disease activity index; EULAR, European League Against Rheumatism; GDA, global disease activity; HRQOL, health-related quality of life; MFI, multidimensional fatigue inventory; pSS, primary SS; RF, rheumatoid factor; RTX, rituximab; SF-36, 36-Item Short Form Health Survey; SG, salivary gland; SS, Sjögren syndrome; SSRI, SS responder index; SWS, stimulated whole saliva; UWS, unstimulated whole saliva; VAS, Visual Analog Scale. 
Salivary gland B cell infiltration would be important to determine the efficacy of RTX even if its role has not yet been completely elucidated; the studies published are difficult to be compared as they report opposite results but they do significantly differ about methodology. ${ }^{63,64}$

Many reasons could be evoked to explain why biological therapies are ineffective in SS randomized trials. In a recent paper, the authors gave many possible explanations: incorrect diagnosis, nonrepresentative SS population enrolled in clinical trials, antinuclear antibody (ANA) false negativity, lack of marker for fatigue and other benign symptoms, and an unknown link between immune system and central nervous system. ${ }^{65}$

\section{RTX in systemic sclerosis (SSc)}

$\mathrm{B}$ cells play a central role in SSc pathogenesis. A mounting quantity of evidences provides a rationale for the use of RTX in SSc patients. ${ }^{66-68}$ The most significant studies on RTX in SSc are reported in Table 3.

RTX was initially administered in patients affected by chronic graft-versus-host disease with a good response on skin fibrosis but not on extra-cutaneous manifestations. ${ }^{69}$
Uncontrolled studies and case reports described the efficacy of RTX in SSc patients with regard to pulmonary function, skin fibrosis, and less frequently arthritis, calcinosis and quality of life. ${ }^{70-80}$

A retrospective case-control analysis performed by the European Scleroderma Trial and Research Group described $63 \mathrm{SSc}$ patients treated with RTX matched to 25 controls; authors described an improvement in skin involvement as assessed by modified Rodnan skin score and a stabilization of lung function as assessed by pulmonary lung function. ${ }^{81}$

Bosello et a ${ }^{82}$ described, in a cohort of $20 \mathrm{SSc}$ patients, the effectiveness of RTX with regard to skin fibrosis and disease activity.

A recent published work by Daoussis et a ${ }^{83}$ showed a beneficial effect on lung involvement of RTX on 33 patients with a follow-up up to 7 years.

Due to heterogeneity of these studies (different dosages and modalities of administration, number of cycles and follow-up period, indications and end points) it would be very problematic to draw definitive conclusions. Not enough data are currently available in the literature to prescribe

Table 3 Results from the off-label use of RTX in SSc

\begin{tabular}{|c|c|c|c|c|}
\hline Studies & Study design & $\begin{array}{l}\text { Number of } \\
\text { patients }\end{array}$ & Drug regimen & Results \\
\hline $\begin{array}{l}\text { Lafyatis } \\
\text { et } \mathrm{al}^{71}\end{array}$ & $\begin{array}{l}\text { Open-label } \\
\text { Observational }\end{array}$ & $15 \mathrm{dcSSc}$ & RTX I g 2 weeks apart & $\begin{array}{l}\text { Primary outcome: } \\
\text { Change in mRSS at } 6 \text { months: no change } \\
\text { Secondary outcomes: } \\
\text { PFTs: stable } \\
\text { Organ involvement: stable } \\
\text { B cell infiltrates: depleted (vs baseline) } \\
\text { Autoantibodies: modest changes }\end{array}$ \\
\hline $\begin{array}{l}\text { Bosello } \\
\text { et } \mathrm{al}^{72}\end{array}$ & Open-label & $9 \mathrm{SSc}$ & RTX I g 2 weeks apart & $\begin{array}{l}\text { Follow-up up to } 36 \text { months (skin biopsy at baseline and during } \\
\text { the follow-up): } \\
\text { After } 6 \text { months; skin score, disease activity index and disease } \\
\text { severity index: decreased } \\
\text { IL-6: reduced } \\
\text { Serum B cells: reduced in seven patients } \\
\text { B cells at baseline in three patients }\end{array}$ \\
\hline $\begin{array}{l}\text { Daoussis } \\
\text { et } \mathrm{al}^{73}\end{array}$ & Open-label & $8 \mathrm{dcSS} c$ with ILD & $\begin{array}{l}\text { RTX } 375 \mathrm{mg} / \mathrm{m}^{2} / \text { week for } \\
4 \text { weeks }\end{array}$ & $\begin{array}{l}\text { Long-term ( } 2 \text { years) safety and efficacy: } \\
\text { Lung involvement (PFTs and HRCT): improved } \\
\text { Skin involvement (mRSS and myofibroblast): improved }\end{array}$ \\
\hline Smith et $\mathrm{al}^{74}$ & Open-label & $8 \mathrm{dcSSc}$ & RTX I g 2 weeks apart & $\begin{array}{l}\text { 24-week follow-up: } \\
\text { Peripheral CDI9+: reduced } \\
\text { Skin sclerosis score: reduced } \\
\text { Biopsies (dermal hyalinized collagen content and dermal } \\
\text { myofibroblast numbers): change }\end{array}$ \\
\hline Smith et $\mathrm{al}^{75}$ & Open-label & $8 \mathrm{dcSSc}$ & $\begin{array}{l}\text { RTX I g } 2 \text { weeks apart at } \\
\text { baseline and after } 6 \text { months }\end{array}$ & $\begin{array}{l}\text { 2-year follow-up: } \\
\text { mRSS: decreased } \\
\text { DAS: decreased } \\
\text { Internal organ involvement: stable } \\
\text { B cell depletion } \\
\text { Biopsies (hyalinized collagen score): change }\end{array}$ \\
\hline
\end{tabular}


Table 3 (Continued)

\begin{tabular}{|c|c|c|c|c|}
\hline Studies & Study design & $\begin{array}{l}\text { Number of } \\
\text { patients }\end{array}$ & Drug regimen & Results \\
\hline $\begin{array}{l}\text { Moazedi- } \\
\text { Fuerst et al }{ }^{76}\end{array}$ & Open-label & $\begin{array}{l}5 \text { SSc with ILD } \\
\text { nonresponders } \\
\text { to CYC }\end{array}$ & $\begin{array}{l}\text { RTX } 500 \text { mg } 2 \text { weeks apart } \\
\text { every } 3 \text { months for I year }\end{array}$ & $\begin{array}{l}\text { mRSS: decreased } \\
\text { DLCO and FVC: increased } \\
\text { Lung fibrosis (three patients): decreased } \\
\text { Digital ulcerations: healed } \\
\text { Severity of Raynaud's phenomenon and vascular pain: decreased } \\
\text { Number of capillary bleeds and megacapillaries: decreased } \\
\text { B-lymphocyte count decreased } \\
\text { Serum immunoglobulins, autoantibody titers or CRP levels: } \\
\text { no change }\end{array}$ \\
\hline $\begin{array}{l}\text { Giuggioli } \\
\text { et } \mathrm{al}^{77}\end{array}$ & Open-label & $10 \mathrm{SSc}$ & $\begin{array}{l}\text { One or more cycles of RTX } \\
375 \mathrm{mg} / \mathrm{m}^{2} / \text { week for } 4 \text { weeks }\end{array}$ & $\begin{array}{l}\text { Follow-up at } 6 \text { months and at last follow-up (up to } 72 \text { months): } \\
\text { mRSS: decreased at } 6 \text { months } \\
\text { Other cutaneous manifestations (hypermelanosis, pruritus, } \\
\text { calcinosis): improved } \\
\text { Arthritis: improved } \\
\text { ILD: stable in } 6 \text { and worsened in } 2 \\
\text { Pro-inflammatory cytokines: a more or less pronounced } \\
\text { reduction after the first RTX cycle }\end{array}$ \\
\hline $\begin{array}{l}\text { Daoussis } \\
\text { et } \mathrm{al}^{78}\end{array}$ & Randomized & $14 \mathrm{SSc}$ & $\begin{array}{l}\text { 8: RTX } 375 \mathrm{~m}^{2} \text { weekly for } \\
4 \text { weeks at baseline and } \\
\text { at } 24 \text { weeks plus standard } \\
\text { therapy } \\
\text { 6: standard treatment alone }\end{array}$ & $\begin{array}{l}\text { I-year follow-up: } \\
\text { FVC, DLCO and skin involvement: increased }\end{array}$ \\
\hline Jordan et $\mathrm{a}^{|8|}$ & $\begin{array}{l}\text { Registry } \\
\text { Case-control }\end{array}$ & $88 \mathrm{SSc}$ & $\begin{array}{l}\text { 63: RTX I g } 2 \text { weeks apart } \\
\text { 25: controls }\end{array}$ & $\begin{array}{l}\text { Primary end point: } \\
\text { mRSS: reduced better in RTX } \\
\text { Secondary end points: } \\
\text { FVC: no further decline } \\
\text { Safety measures: good }\end{array}$ \\
\hline $\begin{array}{l}\text { Bosello } \\
\text { et al }\end{array}$ & Open-label & $\begin{array}{l}29 \text { dcSSc with or } \\
\text { without ILD }\end{array}$ & $\begin{array}{l}\text { RTX I g } 2 \text { weeks apart } \\
\text { (more courses when needed) }\end{array}$ & $\begin{array}{l}\text { Follow-up up to } 68.9 \text { months: } \\
\text { Skin score, activity and severity indices improved significantly } \\
\text { after } 12 \text { months and at final follow-up compared to baseline } \\
\text { FVC and TLC: increased } \\
\text { DLCO: stable } \\
\text { HRCT: stable in } 80 \% \text { of patients }\end{array}$ \\
\hline $\begin{array}{l}\text { Daoussis } \\
\text { et } \mathrm{al}^{83}\end{array}$ & $\begin{array}{l}\text { Multicenter } \\
\text { Open-label }\end{array}$ & 5I SSc with ILD & $\begin{array}{l}\text { 33: } \mathrm{RTX} 375 \mathrm{~m}^{2} \text { weekly for } \\
4 \text { weeks } \\
\text { 18: conventional therapy }\end{array}$ & $\begin{array}{l}\text { Median follow-up } 4 \text { years (up to } 7 \text { years): } \\
\text { FVC: increased at } 2 \text {-year follow-up, results confirmed at } \\
7 \text { years } \\
\text { mRSS: outcome favorable to RTX at all times }\end{array}$ \\
\hline
\end{tabular}

Abbreviations: CRP, C-reactive protein; CYC, cyclophosphamide; DAS, Disease Activity Score; dcSSc, diffuse cutaneous SSc; DLCO, carbon monoxide diffusing capacity; FVC, forced vital capacity; HRCT, high-resolution computed tomography; IL-6, interleukin-6; ILD, interstitial lung disease; mRSS, Rodnan skin thickness score; PFTs, pulmonary function tests; RTX, rituximab; SSc, systemic sclerosis; TLC, total lung capacity.

RTX in SSc patients who are naive to conventional therapy. RTX treatment seems to be promising in lung, skin and articular involvement secondary to SSc. There are little data on calcinosis, where RTX can be considered as a rescue therapy. A prospective, placebo-controlled, randomized trial is needed to definitively assess the efficacy of RTX in SSc. Meanwhile, RTX can be considered as a valid option in those patients who cannot tolerate or have contraindications for conventional therapies (ie, cyclophosphamide) or in patients where conventional therapies have already failed. RTX would be useful in pulmonary involvement as a maintenance therapy after induction with cyclophosphamide.

\section{RTX in spondyloarthritis}

The efficacy of RTX has also been tested in spondyloarthritis. A prospective open-label study showed that, among 20 patients with ankylosing spondylitis, $40 \%$ of anti-TNFnaive patients $(\mathrm{N}=10)$ achieved an improvement in Assessment of SpondyloArthritis international Society (ASAS) and $50 \%$ in Bath Ankylosing Spondylitis Disease Activity Index (BASDAI), while RTX did not seem to be effective in the TNF failure $(\mathrm{N}=10) .{ }^{84}$ Moreover, the same authors reported that five patients who flared on follow-up responded again when retreated with RTX. ${ }^{85}$

Thus, these studies include a small number of patients and are open label, and no clear conclusions can be drawn. 
Further studies are needed to ascertain the real therapeutic role of RTX.

\section{Idiopathic inflammatory myopathies (IIMs)}

IIMs include adult polymyositis (PM) and dermatomyositis (DM), juvenile PM and DM, anti-synthetase syndrome (ASS) and inclusion body myositis.

According to 2012 Cochrane review focused on therapy in DM and PM, no adequately designed study is present in the literature to assess which immunosuppressive drug is the best corticosteroid-sparing agent. ${ }^{86}$ As a result, the drug choice is often based on empirical considerations.

Since up to $80 \%$ of patients with IIMs show circulating autoantibodies and B cells that are found within inflamed muscle fibers, RTX therapy seems to be reasonable. ${ }^{87}$

Although the use of RTX in IIMs is rational and several uncontrolled trials suggested its utility, the RTX in myositis (RIM) trial, conducted on 195 patients, failed to reach both primary and secondary end points; ${ }^{88}$ however, almost $80 \%$ of patients responded to RTX treatment.

A subanalysis of RIM trial also demonstrated RTX as effective in refractory skin involvement in patients with both adult and juvenile DM. ${ }^{89}$

Some evidence suggests that RTX might be useful in interstitial lung disease secondary to IIMs, especially when related to ASS. ${ }^{90-93}$

The presence of antibodies predicts a good response to RTX. ${ }^{94,95}$ Moreover, their titers decrease after therapy with variable correlation with disease activity and muscle enzyme. ${ }^{96}$

\section{RTX biosimilars}

RTX patents expired in Europe in 2013 and in the USA in 2016. Various Phases I, II and III clinical trials are ongoing (JHL1101, ABP 798, MabionCD20, PF-05280586, RTXM83, SAIT101, CT-P10, GP-2013).

European Medicines Agency (EMA) has recently approved the first RTX biosimilar, CT-P10, in RA. In the pivotal trial, patients with active RA were randomly assigned (2:1), to receive CT-P10 1,000 mg or RTX 1,000 mg 2 weeks apart. Patients were randomized to receive the treatment (50 patients for each group). Additional 50 patients were recruited to the CT-P10 group to better assess its safety. CT-P10 was demonstrated to be equivalent regarding pharmacokinetics and efficacy with similar immunogenicity and safety profiles as the originator. ${ }^{97}$

Moreover, patients who completed the follow-up at 72 weeks $(\mathrm{N}=87: 58$ in the CT-P10 group and 29 in the RTX group) entered into the open-label extension study for
56 weeks. Patients of each group received CT-P10 according to DAS28. Patients who switched from RTX to CT-P10 demonstrated comparable efficacy and safety profiles compared to those who maintained CT-P10. In RA patients, maintained CT-P10 was also well tolerated and effective up to 2 years. ${ }^{98}$

EMA is also currently evaluating GP2013 in RA. GP2013 has been demonstrated to be comparable to the originator in a trial recently published as an abstract. ${ }^{99}$

PF-05280586 was proven to be similar to the EU and US originator with regard to pharmacokinetics, CD19 depletion, antidrugs antibodies production and adverse events in RA patients. ${ }^{100}$

Moreover, RTX biosimilars (BCD-020, Baball and MabTas) have been licensed in countries where regulatory processes are not as strict as FDA and EMA recommendations.

Of note, other biosimilars (ie, infliximab and etanercept) have been successfully introduced in the treatment of RA. Biosimilars have no clinical meaningful differences, in terms of efficacy and safety with respect to the originator; thanks to cost saving, they should be considered and their use should be promoted. The availability of biosimilars would allow patients to receive medications that might otherwise be unaffordable to them. ${ }^{101}$

\section{RTX in pregnancy}

RTX was shown not to have any teratogenic effect in animals. ${ }^{102}$ In human beings, when RTX is administered during the second and third trimester, similar levels are found in mother and cord blood. ${ }^{103,104}$

Chakravarty et al ${ }^{105}$ reported 153 pregnancies exposed to RTX in patients affected by RA, non-Hodgkin lymphoma and other autoimmune diseases: 90 live births ( 22 premature and one extremely premature births), 33 miscarriages, 28 elective terminations, one late fetal loss and one maternal death due to cerebral hemorrhage in idiopathic thrombocytopenic purpura. Among live births, two congenital malformations, one death for unknown causes (at 6 months), 11 hematological abnormalities without infectious complication and four neonatal infections were reported. ${ }^{105}$ In particular, 21 patients received RTX during the second or third trimester, among them no maternal death, neonatal death or congenital malformations were noted, whereas cytopenia was reported in seven newborns. ${ }^{105}$

RTX exposure before conception or during early pregnancy does not provoke B cell depletion in newborns, whereas during the late stage of pregnancy (second and third trimester) RTX is able to reduce B cells that usually normalize after 3-6 months. Mothers and newborns, exposed 
to RTX during second and third trimester, should be monitored for the risk of infections since neutropenia and B cell depletion have been described in newborns. ${ }^{104,106-108}$

Although no fetus damage has been reported in pregnancies exposed to RTX during the first trimester, this therapy, according to EULAR recommendations, should be considered only when no other therapeutic option is available.

According to the British Society of Rheumatology (BSR) and British Health Professionals in Rheumatology(BHPR) guidelines on prescribing drugs in pregnancy and breastfeeding, an effective contraception is recommended while taking RTX and for 12 months following treatment. ${ }^{109}$

According to EULAR recommendations, when RTX is administered before week 22 , vaccinations can be performed according to local guidelines (live vaccines included). When administered later in pregnancy, live vaccines should be avoided till 6 months of life. Due to the lack of data, lactation should be avoided. ${ }^{110}$

\section{Miscellaneous}

RTX has been shown to impact on vaccine immunogenicity, thus highlighting the importance of the right timing of vaccines in relation to RTX administration. ${ }^{111}$ For this reason, the better results in terms of humoral response are reported 6 months or more after RTX dosing. ${ }^{112,113}$ Vaccinations should be considered at least 4 weeks before RTX administration. In particular, a significant humoral response impairment has been reported for influenza and pneumococcal vaccinations. ${ }^{112-117}$ No data are available on the effects of RTX on hepatitis B virus (HBV), human papilloma virus or yellow fever vaccines. Safety for live vaccines has not been studied in patients treated with RTX; thus, these vaccines are considered contraindicated in this setting.

Screening serologies for $\mathrm{HBV}$ and hepatitis $\mathrm{C}$ virus (HCV) must be undertaken even if resolved HBV hepatitis reactivation has been rarely reported. ${ }^{118,119}$

In patients with $\mathrm{HBsAg}$ and anti-HBc negativity, vaccination should be considered before RTX initiation. By contrast, patients who are HBsAg and/or anti-HBc positive should be referred to a hepatologist for consideration of a prophylactic therapy, and HBV DNA levels have to be closely monitored if RTX is administered. ${ }^{118,119}$

With regard to $\mathrm{HCV}$, RTX is used in the treatment of HCV-induced cryoglobulinemia. HCV should be screened, and for chronic HCV carriers, collaboration with a hepatologist is mandatory to plan a treatment strategy. ${ }^{18,120}$

Before RTX administration, routine screening for tuberculosis is suggested, even if it is not currently believed to be necessary. Patients with active tuberculosis should be appropriately treated and RTX should not be initiated. ${ }^{121}$

The long-term RTX safety report highlighted that serious opportunistic infections were rare. Among these, the reactivation of the John Cunningham (JC) virus leading to progressive multifocal leukoencephalopathy has been reported in patients with autoimmune diseases who should be informed of this risk. ${ }^{122}$

Finally, it is well known that long-term RTX administration is associated with hypogammaglobulinemia whose consequences are still unclear. It is recommended to evaluate baseline immunoglobulin levels and to consider cessation of therapy when the IgG level drops progressively. ${ }^{123}$

Moreover, attention should be paid to late-onset neutropenia that has been described as a potential RTX-related adverse event. ${ }^{124}$

\section{Conclusion}

RTX is currently considered useful and a relatively safe biological agent in the treatment of some rheumatic diseases.

Although RTX has been demonstrated to be relatively safe for infections, particular attention should be paid in the presence of HBV for the risk of reactivation.

Pregnancy during RTX treatment should be avoided since RTX, especially when administered during second and third trimester, increases the risk of infection in the mother and in the newborn.

RTX has been demonstrated useful in RA and AAV, and it is currently approved in many countries with these indications. RTX is also administered in other rheumatic conditions, such as SLE, SS and SSc, refractory to conventional therapies, but its utility in these conditions has not yet been completely and fully elucidated.

Moreover, further studies are needed to clarify some controversial points such as the association with concomitant DMARDs, RTX dosage and the optimal interval for retreatment. The availability of approved RTX biosimilars, such as CT-P10, would allow a widespread access of this treatment with cost saving. More likely, the harmonization of guidelines and recommendations on the use of biosimilars will be of help in clinical practice.

\section{Author contributions}

All authors contributed toward data analysis, drafting and critically revising the paper and agree to be accountable for all aspects of the work.

\section{Disclosure}

The authors report no conflicts of interest in this work. 


\section{References}

1. Dorner T, Burmester GR. The role of B cells in rheumatoid arthritis: mechanisms and therapeutic targets. Curr Opin Rheumatol. 2003;15(3):246-252.

2. Olsen NJ, Stein CM. New drugs for rheumatoid arthritis. $N$ Engl J Med. 2004;350(21):2167-2179.

3. Food and Drug Administration. [webpage on the Internet]. Questions and Answers on Rituximab (added 12/19/2006). Available from: https://wayback.archive-it.org/7993/20170722191606/https://www.fda. gov/Drugs/DrugSafety/PostmarketDrugSafetyInformationforPatients andProviders/ucm109107.htm. Accessed August 9, 2017.

4. Edwards JC, Szczepanski L, Szechinski J, et al. Efficacy of B-celltargeted therapy with rituximab in patients with rheumatoid arthritis. N Engl J Med. 2004;350(25):2572-2581.

5. Emery P, Fleischmann R, Filipowicz-Sosnowska A, et al. The efficacy and safety of rituximab in patients with active rheumatoid arthritis despite methotrexate treatment: results of a phase IIB randomized, double-blind, placebo-controlled, dose-ranging trial. Arthritis Rheum. 2006;54(5):1390-1400.

6. Rubbert-Roth A, Tak PP, Zerbini C, et al. Efficacy and safety of various repeat treatment dosing regimens of rituximab in patients with active rheumatoid arthritis: results of a phase III randomized study (MIRROR). Rheumatology. 2010;49(9):1683-1693.

7. Emery P, Deodhar A, Rigby WF, et al. Efficacy and safety of different doses and retreatment of rituximab: a randomised, placebo-controlled trial in patients who are biological naive with active rheumatoid arthritis and an inadequate response to methotrexate (Study Evaluating Rituximab's Efficacy in MTX iNadequate rEsponders (SERENE)). Ann Rheum Dis. 2010;69(9):1629-1635.

8. Cohen SB, Emery P, Greenwald MW, et al. Rituximab for rheumatoid arthritis refractory to anti-tumor necrosis factor therapy: results of a multicenter, randomized, double-blind, placebo-controlled, phase III trial evaluating primary efficacy and safety at twenty-four weeks. Arthritis Rheum. 2006;54(9):2793-2806.

9. Cohen SB, Keystone E, Genovese MC, et al. Continued inhibition of structural damage over 2 years in patients with rheumatoid arthritis treated with rituximab in combination with methotrexate. Ann Rheum Dis. 2010;69(6):1158-1161.

10. Mease PJ, Cohen S, Gaylis NB, et al. Efficacy and safety of retreatment in patients with rheumatoid arthritis with previous inadequate response to tumor necrosis factor inhibitors: results from the SUNRISE trial. J Rheumatol. 2010;37(5):917-927.

11. Haraoui B, Bokarewa M, Kallmeyer I, Bykerk VP, Investigators R. Safety and effectiveness of rituximab in patients with rheumatoid arthritis following an inadequate response to 1 prior tumor necrosis factor inhibitor: the RESET Trial. J Rheumatol. 2011;38(12):2548-2556.

12. Emery P, Gottenberg JE, Rubbert-Roth A, et al. Rituximab versus an alternative TNF inhibitor in patients with rheumatoid arthritis who failed to respond to a single previous TNF inhibitor: SWITCH-RA, a global, observational, comparative effectiveness study. Ann Rheum Dis. 2015;74(6):979-984.

13. Ingegnoli F, Castelli R, Gualtierotti R. Rheumatoid factors: clinical applications. Dis Markers. 2013;35(6):727-734.

14. Gomez-Reino JJ, Maneiro JR, Ruiz J, et al. Comparative effectiveness of switching to alternative tumour necrosis factor (TNF) antagonists versus switching to rituximab in patients with rheumatoid arthritis who failed previous TNF antagonists: the MIRAR Study. Ann Rheum Dis. 2012;71(11):1861-1864.

15. Ingegnoli F, Favalli EG, Meroni PL. Does polymorphism of genes coding for pro-inflammatory mediators predict the clinical response to tnf alpha blocking agents? A review analysis of the literature. Autoimmun Rev. 2011;10(8):460-463.

16. Tak PP, Rigby WF, Rubbert-Roth A, et al. Inhibition of joint damage and improved clinical outcomes with rituximab plus methotrexate in early active rheumatoid arthritis: the IMAGE trial. Ann Rheum Dis. 2011; 70(1):39-46.
17. Tak PP, Rigby W, Rubbert-Roth A, et al. Sustained inhibition of progressive joint damage with rituximab plus methotrexate in early active rheumatoid arthritis: 2-year results from the randomised controlled trial IMAGE. Ann Rheum Dis. 2012;71(3):351-357.

18. Mok CC. Rituximab for the treatment of rheumatoid arthritis: an update. Drug Des Devel Ther. 2013;8:87-100.

19. Jennette JC, Falk RJ, Bacon PA, et al. 2012 revised International Chapel Hill Consensus Conference Nomenclature of Vasculitides. Arthritis Rheum. 2013;65(1):1-11.

20. Keogh KA, Limper AH. Characterization of lymphocyte populations in nonspecific interstitial pneumonia. Respir Res. 2005;6:137.

21. Keogh KA, Ytterberg SR, Fervenza FC, Carlson KA, Schroeder DR, Specks U. Rituximab for refractory Wegener's granulomatosis: report of a prospective, open-label pilot trial. Am J Respir Crit Care Med. 2006; 173(2):180-187.

22. Stone JH, Merkel PA, Spiera R, et al. Rituximab versus cyclophosphamide for ANCA-associated vasculitis. N Engl J Med. 2010;363(3):221-232.

23. Specks U, Merkel PA, Seo P, et al. Efficacy of remission-induction regimens for ANCA-associated vasculitis. N Engl J Med. 2013;369(5): 417-427.

24. Fussner LA, Hummel AM, Schroeder DR, et al. Factors determining the clinical utility of serial measurements of antineutrophil cytoplasmic antibodies targeting proteinase 3. Arthritis Rheumatol. 2016; 68(7):1700-1710.

25. Guillevin L, Pagnoux C, Karras A, et al. Rituximab versus azathioprine for maintenance in ANCA-associated vasculitis. N Engl J Med. 2014; 371(19):1771-1780.

26. Gopaluni S, Smith RM, Lewin M, et al. Rituximab versus azathioprine as therapy for maintenance of remission for anti-neutrophil cytoplasm antibody-associated vasculitis (RITAZAREM): study protocol for a randomized controlled trial. Trials. 2017;18(1):112.

27. Sanz I, Lee FE. B cells as therapeutic targets in SLE. Nat Rev Rheumatol. 2010;6(6):326-337.

28. Leandro MJ, Cambridge G, Edwards JC, Ehrenstein MR, Isenberg DA. B-cell depletion in the treatment of patients with systemic lupus erythematosus: a longitudinal analysis of 24 patients. Rheumatology. 2005; 44(12):1542-1545.

29. Lu TY, Ng KP, Cambridge G, et al. A retrospective seven-year analysis of the use of B cell depletion therapy in systemic lupus erythematosus at University College London Hospital: the first fifty patients. Arthritis Rheum. 2009;61(4):482-487.

30. Diaz-Lagares C, Croca S, Sangle S, et al. Efficacy of rituximab in 164 patients with biopsy-proven lupus nephritis: pooled data from European cohorts. Autoimmun Rev. 2012;11(5):357-364.

31. Lightstone L. The landscape after LUNAR: rituximab's crater-filled path. Arthritis Rheum. 2012;64(4):962-965.

32. Condon MB, Ashby D, Pepper RJ, et al. Prospective observational single-centre cohort study to evaluate the effectiveness of treating lupus nephritis with rituximab and mycophenolate mofetil but no oral steroids. Ann Rheum Dis. 2013;72(8):1280-1286.

33. Witt M, Grunke M, Proft F, et al. Clinical outcomes and safety of rituximab treatment for patients with systemic lupus erythematosus (SLE) - results from a nationwide cohort in Germany (GRAID). Lupus. 2013;22(11):1142-1149.

34. Wilhelmus S, Bajema IM, Bertsias GK, et al. Lupus nephritis management guidelines compared. Nephrol Dial Transplant. 2016;31(6):904-913.

35. Merrill JT, Neuwelt CM, Wallace DJ, et al. Efficacy and safety of rituximab in moderately-to-severely active systemic lupus erythematosus: the randomized, double-blind, phase II/III systemic lupus erythematosus evaluation of rituximab trial. Arthritis Rheum. 2010;62(1):222-233.

36. Rovin BH, Furie R, Latinis K, et al. Efficacy and safety of rituximab in patients with active proliferative lupus nephritis: the Lupus Nephritis Assessment with Rituximab study. Arthritis Rheum. 2012;64(4): 1215-1226.

37. Albert D, Dunham J, Khan S, et al. Variability in the biological response to anti-CD20 B cell depletion in systemic lupus erythaematosus. Ann Rheum Dis. 2008;67(12):1724-1731. 
38. Lindholm C, Borjesson-Asp K, Zendjanchi K, Sundqvist AC, Tarkowski A, Bokarewa M. Longterm clinical and immunological effects of anti-CD20 treatment in patients with refractory systemic lupus erythematosus. J Rheumatol. 2008;35(5):826-833.

39. Ramos-Casals M, Garcia-Hernandez FJ, de Ramon E, et al. Off-label use of rituximab in 196 patients with severe, refractory systemic autoimmune diseases. Clin Exp Rheumatol. 2010;28(4):468-476.

40. Vital EM, Dass S, Buch MH, et al. B cell biomarkers of rituximab responses in systemic lupus erythematosus. Arthritis Rheum. 2011; 63(10):3038-3047.

41. Fernandez-Nebro A, de la Fuente JL, Carreno L, et al. Multicenter longitudinal study of B-lymphocyte depletion in refractory systemic lupus erythematosus: the LESIMAB study. Lupus. 2012;21(10):1063-1076.

42. Terrier B, Amoura Z, Ravaud P, et al. Safety and efficacy of rituximab in systemic lupus erythematosus: results from 136 patients from the French AutoImmunity and Rituximab registry. Arthritis Rheum. 2010;62(8):2458-2466.

43. Wang CR, Liu MF. Rituximab usage in systemic lupus erythematosusassociated antiphospholipid syndrome: a single-center experience. Semin Arthritis Rheum. 2016;46(1):102-108.

44. Tokunaga M, Saito K, Kawabata D, et al. Efficacy of rituximab (antiCD20) for refractory systemic lupus erythematosus involving the central nervous system. Ann Rheum Dis. 2007;66(4):470-475.

45. Pinto LF, Velasquez CJ, Prieto C, Mestra L, Forero E, Marquez JD. Rituximab induces a rapid and sustained remission in Colombian patients with severe and refractory systemic lupus erythematosus. Lupus. 2011;20(11):1219-1226.

46. Kotagiri P, Martin A, Hughes P, Becker G, Nicholls K. Single-dose rituximab in refractory lupus nephritis. Intern Med J. 2016;46(8): 899-901.

47. Simonetta F, Allali D, Roux-Lombard P, Chizzolini C. Successful treatment of refractory lupus nephritis by the sequential use of rituximab and belimumab. Joint Bone Spine. 2016;84(2):235-236.

48. Ryden-Aulin M, Boumpas D, Bultink I, et al. Off-label use of rituximab for systemic lupus erythematosus in Europe. Lupus Sci Med. 2016; 3(1): 000163

49. Cornec D, Devauchelle-Pensec V, Tobon GJ, Pers JO, Jousse-Joulin S, Saraux A. B cells in Sjogren's syndrome: from pathophysiology to diagnosis and treatment. J Autoimmun. 2012;39(3):161-167.

50. Dass S, Bowman SJ, Vital EM, et al. Reduction of fatigue in Sjogren syndrome with rituximab: results of a randomised, double-blind, placebocontrolled pilot study. Ann Rheum Dis. 2008;67(11):1541-1544.

51. Meijer JM, Meiners PM, Vissink A, et al. Effectiveness of rituximab treatment in primary Sjogren's syndrome: a randomized, double-blind, placebo-controlled trial. Arthritis Rheum. 2010;62(4):960-968.

52. Devauchelle-Pensec V, Mariette X, Jousse-Joulin S, et al. Treatment of primary Sjogren syndrome with rituximab: a randomized trial. Ann Intern Med. 2014;160(4):233-242.

53. Souza FB, Porfirio GJ, Andriolo BN, Albuquerque JV, Trevisani VF. Rituximab effectiveness and safety for treating primary Sjogren's syndrome (pSS): systematic review and meta-analysis. PLoS One. 2016; 11(3):e0150749.

54. Carubbi F, Cipriani P, Marrelli A, et al. Efficacy and safety of rituximab treatment in early primary Sjogren's syndrome: a prospective, multicenter, follow-up study. Arthritis Res Ther. 2013;15(5):R172.

55. Cornec D, Devauchelle-Pensec V, Mariette X, et al. Development of the Sjogren's Syndrome Responder Index, a data-driven composite endpoint for assessing treatment efficacy. Rheumatology. 2015;54(9): 1699-1708

56. Jousse-Joulin S, Devauchelle-Pensec V, Cornec D, et al. Brief report: ultrasonographic assessment of salivary gland response to rituximab in primary Sjogren's syndrome. Arthritis Rheumatol. 2015;67(6): $1623-1628$

57. Carsons SE, Vivino FB, Parke A, et al. Treatment guidelines for rheumatologic manifestations of Sjogren's syndrome: use of biologic agents, management of fatigue, and inflammatory musculoskeletal pain. Arthritis Care Res. 2016;69(4):517-527.
58. De Vita S, Quartuccio L, Salvin S, et al. Sequential therapy with belimumab followed by rituximab in Sjogren's syndrome associated with B-cell lymphoproliferation and overexpression of BAFF: evidence for long-term efficacy. Clin Exp Rheumatol. 2014;32(4): 490-494.

59. Mariette X, Seror R, Quartuccio L, et al. Efficacy and safety of belimumab in primary Sjogren's syndrome: results of the BELISS openlabel phase II study. Ann Rheum Dis. 2015;74(3):526-531.

60. Chen MH, Chen CK, Chou HP, Chen MH, Tsai CY, Chang DM. Rituximab therapy in primary Sjogren's syndrome with interstitial lung disease: a retrospective cohort study. Clin Exp Rheumatol. 2016; 34(6):1077-1084.

61. Gottenberg JE, Cinquetti G, Larroche C, et al. Efficacy of rituximab in systemic manifestations of primary Sjogren's syndrome: results in 78 patients of the AutoImmune and Rituximab registry. Ann Rheum Dis. 2013;72(6):1026-1031.

62. Meiners PM, Arends S, Meijer JM, et al. Efficacy of retreatment with rituximab in patients with primary Sjogren's syndrome. Clin Exp Rheumatol. 2015;33(3):443-444.

63. Cornec D, Costa S, Devauchelle-Pensec V, et al. Blood and salivary-gland BAFF-driven B-cell hyperactivity is associated to rituximab inefficacy in primary Sjogren's syndrome. J Autoimmun. 2016;67:102-110.

64. Delli K, Haacke EA, Kroese FG, et al. Towards personalised treatment in primary Sjogren's syndrome: baseline parotid histopathology predicts responsiveness to rituximab treatment. Ann Rheum Dis. 2016;75(11):1933-1938.

65. Fox RI, Fox CM. Sjogren syndrome: why do clinical trials fail? Rheum Dis Clin North Am. 2016;42(3):519-530.

66. Bosello S, De Luca G, Tolusso B, et al. B cells in systemic sclerosis: a possible target for therapy. Autoimmun Rev. 2011;10(10):624-630.

67. Ingegnoli F, Trabattoni D, Saresella M, Fantini F, Clerici M. Distinct immune profiles characterize patients with diffuse or limited systemic sclerosis. Clin Immunol. 2003;108(1):21-28.

68. Ingegnoli F, Gualtierotti R, Schioppo T, et al. Fibrosis biomarkers in isolated Raynaud's phenomenon: too little, too soon? Ann Rheum Dis. 2014;73(5):940-941.

69. Okamoto M, Okano A, Akamatsu S, et al. Rituximab is effective for steroid-refractory sclerodermatous chronic graft-versus-host disease. Leukemia. 2006;20(1):172-173.

70. McGonagle D, Tan AL, Madden J, et al. Successful treatment of resistant scleroderma-associated interstitial lung disease with rituximab. Rheumatology. 2008;47(4):552-553.

71. Lafyatis R, Kissin E, York M, et al. B cell depletion with rituximab in patients with diffuse cutaneous systemic sclerosis. Arthritis Rheum. 2009;60(2):578-583.

72. Bosello S, De Santis M, Lama G, et al. B cell depletion in diffuse progressive systemic sclerosis: safety, skin score modification and IL-6 modulation in an up to thirty-six months follow-up open-label trial. Arthritis Res Ther. 2010;12(2):R54.

73. Daoussis D, Liossis SN, Tsamandas AC, et al. Effect of long-term treatment with rituximab on pulmonary function and skin fibrosis in patients with diffuse systemic sclerosis. Clin Exp Rheumatol. 2012; 30(2 suppl 71):S17-S22.

74. Smith V, Van Praet JT, Vandooren B, et al. Rituximab in diffuse cutaneous systemic sclerosis: an open-label clinical and histopathological study. Ann Rheum Dis. 2010;69(1):193-197.

75. Smith V, Piette Y, van Praet JT, et al. Two-year results of an open pilot study of a 2-treatment course with rituximab in patients with early systemic sclerosis with diffuse skin involvement. $J$ Rheumatol. 2013;40(1):52-57.

76. Moazedi-Fuerst FC, Kielhauser SM, Brickmann K, et al. Rituximab for systemic sclerosis: arrest of pulmonary disease progression in five cases. Results of a lower dosage and shorter interval regimen. Scand J Rheumatol. 2014;43(3):257-258.

77. Giuggioli D, Lumetti F, Colaci M, Fallahi P, Antonelli A, Ferri C. Rituximab in the treatment of patients with systemic sclerosis. Our experience and review of the literature. Autoimmun Rev. 2015;14(11):1072-1078. 
78. Daoussis D, Liossis SN, Tsamandas AC, et al. Experience with rituximab in scleroderma: results from a 1-year, proof-of-principle study. Rheumatology. 2010;49(2):271-280.

79. Gualtierotti R, Ingegnoli F, Scalone L, et al. Feasibility, acceptability and construct validity of EQ-5D in systemic sclerosis. Swiss Med Wkly. 2017;146:w14394.

80. Ghrenassia E, Avouac J, Khanna D, et al. Prevalence, correlates and outcomes of gastric antral vascular ectasia in systemic sclerosis: a EUSTAR case-control study. J Rheumatol. 2014;41(1):99-105.

81. Jordan S, Distler JH, Maurer B, et al. Effects and safety of rituximab in systemic sclerosis: an analysis from the European Scleroderma Trial and Research (EUSTAR) group. Ann Rheum Dis. 2015;74(6):1188-1194.

82. Bosello SL, De Luca G, Rucco M, et al. Long-term efficacy of B cell depletion therapy on lung and skin involvement in diffuse systemic sclerosis. Semin Arthritis Rheum. 2015;44(4):428-436.

83. Daoussis D, Melissaropoulos K, Sakellaropoulos G, et al. A multicenter, open-label, comparative study of B-cell depletion therapy with Rituximab for systemic sclerosis-associated interstitial lung disease. Semin Arthritis Rheum. 2016;46(5):625-631.

84. Song IH, Heldmann F, Rudwaleit M, et al. Different response to rituximab in tumor necrosis factor blocker-naive patients with active ankylosing spondylitis and in patients in whom tumor necrosis factor blockers have failed: a twenty-four-week clinical trial. Arthritis Rheum. 2010;62(5):1290-1297.

85. Song IH, Heldmann F, Rudwaleit M, et al. One-year follow-up of ankylosing spondylitis patients responding to rituximab treatment and re-treated in case of a flare. Ann Rheum Dis. 2013;72(2):305-306.

86. Gordon PA, Winer JB, Hoogendijk JE, Choy EH. Immunosuppressant and immunomodulatory treatment for dermatomyositis and polymyositis. Cochrane Database Syst Rev. 2012;(8):CD003643.

87. Shinjo SK, de Souza FH, de Moraes JC. Dermatomyositis and polymyositis: from immunopathology to immunotherapy (immunobiologics). Rev Bras Reumatol. 2013;53(1):101-110.

88. Oddis CV, Reed AM, Aggarwal R, et al. Rituximab in the treatmen of refractory adult and juvenile dermatomyositis and adult polymyositis: a randomized, placebo-phase trial. Arthritis Rheum. 2013;65(2): 314-324.

89. Aggarwal R, Loganathan P, Koontz D, Qi Z, Reed AM, Oddis CV. Cutaneous improvement in refractory adult and juvenile dermatomyositis after treatment with rituximab. Rheumatology. 2017;56(2): 247-254.

90. Lambotte O, Kotb R, Maigne G, Blanc FX, Goujard C, Delfraissy JF. Efficacy of rituximab in refractory polymyositis. J Rheumatol. 2005; 32(7):1369-1370.

91. Marie I, Dominique S, Janvresse A, Levesque H, Menard JF. Rituximab therapy for refractory interstitial lung disease related to antisynthetase syndrome. Respir Med. 2012;106(4):581-587.

92. Rider LG, Yip AL, Horkayne-Szakaly I, et al. Novel assessment tools to evaluate clinical and laboratory responses in a subset of patients enrolled in the Rituximab in Myositis trial. Clin Exp Rheumatol. 2014; 32(5):689-696.

93. Andersson H, Sem M, Lund MB, et al. Long-term experience with rituximab in anti-synthetase syndrome-related interstitial lung disease. Rheumatology. 2015;54(8):1420-1428.

94. Mahler EA, Blom M, Voermans NC, van Engelen BG, van Riel PL, Vonk MC. Rituximab treatment in patients with refractory inflammatory myopathies. Rheumatology. 2011;50(12):2206-2213.

95. Reed AM, Crowson CS, Hein M, et al. Biologic predictors of clinical improvement in rituximab-treated refractory myositis. BMC Musculoskelet Disord. 2015;16:257.

96. Aggarwal R, Oddis CV, Goudeau D, et al. Autoantibody levels in myositis patients correlate with clinical response during $\mathrm{B}$ cell depletion with rituximab. Rheumatology. 2016;55(6):991-999.

97. Yoo DH, Suh CH, Shim SC, et al. A multicentre randomised controlled trial to compare the pharmacokinetics, efficacy and safety of CT-P10 and innovator rituximab in patients with rheumatoid arthritis. Ann Rheum Dis. 2017;76(3):566-570.
98. Yoo DH, Park W, Suh CH, et al [webpage on the Internet]. Efficacy and safety of switched CT-P10 from innovator rituximab compared to those of maintained CT-P10 in patients with rheumatoid arthritis up to 56 weeks. Arthritis Rheumatol. 2015;67(suppl 10). Available from: http://acrabstracts.org/abstract/efficacy-and-safety-of-switched-ctp10-from-innovator-rituximab-compared-to-those-of-maintained-ctp10-in-patients-with-rheumatoid-arthritis-up-to-56-weeks/. Accessed July 20, 2017.

99. Smolen J, Scheinberg M, Tony H, et al. FRI0222 pharmacokinetics, pharmacodynamics, safety and efficacy of proposed rituximab biosimilar (GP2013) vs EU-approved rituximab (RTX) in patients with rheumatoid arthritis: results from a randomized controlled trial (GP13-201) over 52 weeks. Ann Rheum Dis. 2016;75:512-513.

100. Cohen S, Emery P, Greenwald M, et al. A phase I pharmacokinetics trial comparing PF-05280586 (a potential biosimilar) and rituximab in patients with active rheumatoid arthritis. Br J Clin Pharmacol. 2016;82(1):129-138.

101. Dorner T, Strand V, Cornes P, et al. The changing landscape of biosimilars in rheumatology. Ann Rheum Dis. 2016;75(6):974-982.

102. Schroder C, Azimzadeh AM, Wu G, Price JO, Atkinson JB, Pierson RN. Anti-CD20 treatment depletes B-cells in blood and lymphatic tissue of cynomolgus monkeys. Transpl Immunol. 2003;12(1):19-28.

103. Decker M, Rothermundt C, Hollander G, Tichelli A, Rochlitz C. Rituximab plus CHOP for treatment of diffuse large B-cell lymphoma during second trimester of pregnancy. Lancet Oncol. 2006;7(8):693-694.

104. Friedrichs B, Tiemann M, Salwender H, Verpoort K, Wenger MK, Schmitz N. The effects of rituximab treatment during pregnancy on a neonate. Haematologica. 2006;91(10):1426-1427.

105. Chakravarty EF, Murray ER, Kelman A, Farmer P. Pregnancy outcomes after maternal exposure to rituximab. Blood. 2011;117(5): 1499-1506.

106. Ostensen M, Forger F. How safe are anti-rheumatic drugs during pregnancy? Curr Opin Pharmacol. 2013;13(3):470-475.

107. Klink DT, van Elburg RM, Schreurs MW, van Well GT. Rituximab administration in third trimester of pregnancy suppresses neonatal B-cell development. Clin Dev Immunol. 2008;2008:271363.

108. Gualtierotti R, Ingegnoli F, Meroni PL. Pre-conceptional exposure to rituximab: comment on the article by Ojeda-Uribe et al. Clin Rheumatol. 2013;32(5):727-728.

109. Flint J, Panchal S, Hurrell A, et al. BSR and BHPR guideline on prescribing drugs in pregnancy and breastfeeding-Part I: standard and biologic disease modifying anti-rheumatic drugs and corticosteroids. Rheumatology. 2016;55(9):1693-1697.

110. Gotestam Skorpen C, Hoeltzenbein M, Tincani A, et al. The EULAR points to consider for use of antirheumatic drugs before pregnancy, and during pregnancy and lactation. Ann Rheum Dis. 2016;75(5):795-810.

111. Friedman MA, Winthrop KL. Vaccines and disease-modifying antirheumatic drugs: practical implications for the rheumatologist. Rheum Dis Clin North Am. 2017;43(1):1-13.

112. Rehnberg M, Brisslert M, Amu S, Zendjanchi K, Hawi G, Bokarewa MI. Vaccination response to protein and carbohydrate antigens in patients with rheumatoid arthritis after rituximab treatment. Arthritis Res Ther. 2010;12(3):R111

113. van Assen S, Holvast A, Benne CA, et al. Humoral responses after influenza vaccination are severely reduced in patients with rheumatoid arthritis treated with rituximab. Arthritis Rheum. 2010;62(1): 75-81.

114. Arad U, Tzadok S, Amir S, et al. The cellular immune response to influenza vaccination is preserved in rheumatoid arthritis patients treated with rituximab. Vaccine. 2011;29(8):1643-1648.

115. Oren S, Mandelboim M, Braun-Moscovici Y, et al. Vaccination against influenza in patients with rheumatoid arthritis: the effect of rituximab on the humoral response. Ann Rheum Dis. 2008;67(7):937-941.

116. Crnkic Kapetanovic M, Saxne T, Jonsson G, Truedsson L, Geborek P. Rituximab and abatacept but not tocilizumab impair antibody response to pneumococcal conjugate vaccine in patients with rheumatoid arthritis. Arthritis Res Ther. 2013;15(5):R171. 
117. Bingham CO 3rd, Looney RJ, Deodhar A, et al. Immunization responses in rheumatoid arthritis patients treated with rituximab: results from a controlled clinical trial. Arthritis Rheum. 2010;62(1):64-74.

118. Ghrenassia E, Mekinian A, Rouaghe S, Ganne N, Fain O. Reactivation of resolved hepatitis B during rituximab therapy for rheumatoid arthritis. Joint Bone Spine. 2012;79(1):100-101.

119. Pyrpasopoulou A, Douma S, Vassiliadis T, Chatzimichailidou S, Triantafyllou A, Aslanidis S. Reactivation of chronic hepatitis B virus infection following rituximab administration for rheumatoid arthritis. Rheumatol Int. 2011;31(3):403-404.

120. Ennishi D, Yokoyama M, Terui Y, et al. Does rituximab really induce hepatitis C virus reactivation? J Clin Oncol. 2008;26(28):4695-4696. author reply 4696.
121. Buch MH, Smolen JS, Betteridge N, et al. Updated consensus statement on the use of rituximab in patients with rheumatoid arthritis. Ann Rheum Dis. 2011;70(6):909-920.

122. Clavel G, Moulignier A, Semerano L. Progressive multifocal leukoencephalopathy and rheumatoid arthritis treatments. Joint Bone Spine. Epub 2017 Mar 18.

123. Casulo C, Maragulia J, Zelenetz AD. Incidence of hypogammaglobulinemia in patients receiving rituximab and the use of intravenous immunoglobulin for recurrent infections. Clin Lymphoma Myeloma Leuk. 2013;13(2):106-111.

124. Breuer GS, Ehrenfeld M, Rosner I, et al. Late-onset neutropenia following rituximab treatment for rheumatologic conditions. Clin Rheumatol. 2014;33(9):1337-1340.

\section{Publish your work in this journal}

Drug Design, Development and Therapy is an international, peerreviewed open-access journal that spans the spectrum of drug design and development through to clinical applications. Clinical outcomes, patient safety, and programs for the development and effective, safe, and sustained use of medicines are the features of the journal, which has also been accepted for indexing on PubMed Central. The manuscript management system is completely online and includes a very quick and fair peer-review system, which is all easy to use. Visit http://www.dovepress.com/testimonials.php to read real quotes from published authors.

Submit your manuscript here: http://www.dovepress.com/drug-design-development-and-therapy-journal 